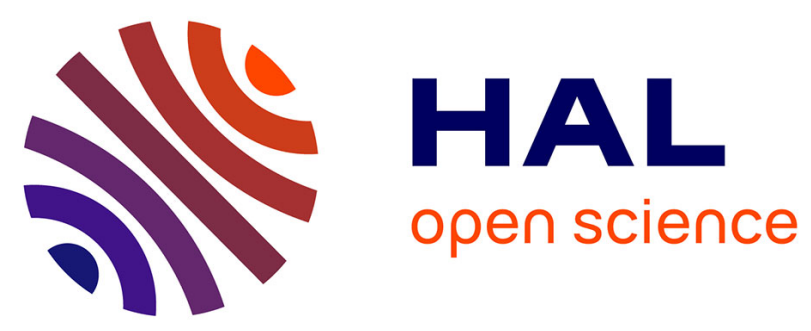

\title{
Environmental factors associated with phytoplankton succession in a Mediterranean reservoir with a highly fluctuating water level
}

\author{
Ali Fadel, Ali Atoui, Bruno J. Lemaire, B. Vinçon-Leite, Kamal Slim
}

\section{To cite this version:}

Ali Fadel, Ali Atoui, Bruno J. Lemaire, B. Vinçon-Leite, Kamal Slim. Environmental factors associated with phytoplankton succession in a Mediterranean reservoir with a highly fluctuating water level. Environmental Monitoring and Assessment, 2015, 187 (10), pp.633. 10.1007/s10661-015-48524. hal-01238358

\section{HAL Id: hal-01238358 \\ https://hal-enpc.archives-ouvertes.fr/hal-01238358}

Submitted on 25 Jan 2018

HAL is a multi-disciplinary open access archive for the deposit and dissemination of scientific research documents, whether they are published or not. The documents may come from teaching and research institutions in France or abroad, or from public or private research centers.
L'archive ouverte pluridisciplinaire HAL, est destinée au dépôt et à la diffusion de documents scientifiques de niveau recherche, publiés ou non, émanant des établissements d'enseignement et de recherche français ou étrangers, des laboratoires publics ou privés. 
This article was published as: Ali Fadel, Ali Atoui, Bruno J. Lemaire, B. Vinçon-Leite, Kamal Slim (2015). Environmental factors associated with phytoplankton succession in a Mediterranean reservoir with a highly fluctuating water level. Environmental Monitoring and Assessment, 187: 633. DOI: $10.1007 / \mathrm{s} 10661-015-4852-4$

\title{
Environmental factors associated with phytoplankton succession in a Mediterranean reservoir with a highly fluctuating water level
}

\author{
Ali Fadel 1,2*, Ali Atoui ${ }^{3}$, Bruno J. Lemaire ${ }^{1,4}$, Brigitte Vinçon-Leite ${ }^{1}$, Kamal Slim ${ }^{3}$ \\ ${ }^{1}$ Université Paris-Est, LEESU (UMR MA-102), Université Paris-Est-Créteil, Ecole des Ponts \\ ParisTech, AgroParisTech, F-77455 Marne-la-Vallée, France; E-Mails: \\ bruno.lemaire@leesu.enpc.fr; $\underline{\text { bvl@ @leesu.enpc.fr }}$ \\ ${ }^{2}$ National Center for Remote Sensing, National Council for Scientific Research (CNRS), P.O. \\ Box 11-8281, Riad El Solh, 11072260 Beirut, Lebanon; E-Mail: afadel@cnrs.edu.lb \\ ${ }^{3}$ Laboratory of Microorganisms and Food Irradiation, Lebanese Atomic Energy Commission- \\ CNRS, P.O. Box 11-8281, Riad El Solh, 11072260 Beirut, Lebanon; E-Mail: a.atoui@ \\ $\underline{\text { cnrs.edu.lb }}, \underline{\text { kslim@ @ cnrs.edu.lb }}$ \\ ${ }^{4}$ AgroParisTech, F-75005 Paris, France \\ *Author to whom correspondence should be addressed; E-Mail: afadel@ cnrs.edu.lb; \\ Tel.: + 961 (0)1 4508 11; Fax: + 961 (0)1 450810
}

\begin{abstract}
Eutrophication and harmful algal blooms have become a worldwide environmental problem. Understanding the mechanisms and processes that control algal blooms is of great concern. The phytoplankton community of Karaoun Reservoir, the largest water body in Lebanon, is poorly studied, as in many freshwater bodies around the Mediterranean Sea. Sampling campaigns were conducted semi-monthly between May 2012 and August 2013 to assess the dynamics of its phytoplankton community in response to changes in physical-chemical and hydrological conditions. Karaoun Reservoir is a monomictic waterbody and strongly stratifies between May and August. Changes in its phytoplankton community were found to be a result of the interplay between water temperature, stratification, irradiance, nutrient availability and water level. Thermal stratification established in spring reduced the growth of diatoms and resulted in their replacement by green algae species when nutrient availability was high and water temperatures lower than $22{ }^{\circ} \mathrm{C}$. At water temperature higher than $25{ }^{\circ} \mathrm{C}$ and low nutrient concentrations in summer, blooms of the cyanobacterium Microcystis aeruginosa occurred. Despite different growth conditions in other lakes and reservoir, cyanobacterium Aphanizomenon ovalisporum dominated at temperatures lower than $23{ }^{\circ} \mathrm{C}$ in weakly stratified conditions in early autumn and dinoflagellate Ceratium hirundinella dominated in mixed conditions, at low light intensity and a water temperature of $19{ }^{\circ} \mathrm{C}$ in late autumn. We believe that the information presented in this paper will increase the knowledge about phytoplankton dynamics in the Mediterranean region and contribute to a safer usage of reservoir waters.
\end{abstract}

Keywords: Cyanobacteria, Irradiance, Middle East, Nutrients, Thermal stratification. 


\section{Introduction}

Eutrophication threatens freshwater bodies as it promotes the development and persistence of harmful algal blooms during warm conditions (Reynolds, 2006a). Many lakes and reservoirs throughout the world are contaminated by harmful algal species (Li et al., 2013), mostly toxic cyanobacteria that can produce cyanotoxins. These toxins cause numerous illnesses and deaths to livestock, pets, wildlife and humans that ingest water contaminated with toxic cyanobacterial cells, or toxins released from decaying cyanobacterial cells (Lance et al., 2010). In addition, these blooms decrease water transparency and reduce the dissolved oxygen concentration in the hypolimnion; they result in fish kills, due to hypoxia and cyanotoxins, and hinder the recreational use of the water bodies (Smith, 2003). The development of phytoplankton populations is mainly controlled by nutrient concentrations, light intensity, the water residence time, water temperature, mixing and grazing (Reynolds, 2006b). Understanding the processes that control algal blooms remains of great concern.

The response of fresh water bodies to water level fluctuations (WLF) is an under-studied field (Zohary and Ostrovsky, 2011). Most of the research studies performed on the environmental factors affecting algal succession and composition were done on lakes and reservoirs with a stable water level. Water level fluctuations can affect phytoplankton biomass and species composition through their effect on mixing processes, biogeochemical processes, oxygen dynamics, and underwater light climate (Naselli-Flores and Barone, 1997; ValdespinoCastillo et al., 2014).

Karaoun Reservoir, the largest water body in Lebanon, was built up in 1965, primarily for agricultural irrigation and hydroelectricity production. This artificial ecosystem now serves varied purposes such as commercial fishing, recreation, tourism, and irrigation. These different uses result in high fluctuation in its water level (Fadel et al., 2014a).

Whereas studies have been carried out in Karaoun Reservoir on toxins (Fadel et al., 2014b) and metal and nutrient concentrations (Korfali and Jurdi, 2010), the few articles which report the occurrence of toxic cyanobacterial blooms do not describe the physical-chemical factors that control phytoplankton blooms (Atoui et al., 2013; Slim et al., 2014). In this study, we try to 1) present the temporal variation of physico-chemical parameters in Karaoun Reservoir, 2) identify its phytoplankton composition, and 3) understand the processes controlling phytoplankton succession in this reservoir with a high water level fluctuation.

\section{Materials and methods}

\subsection{Study site}

Karaoun Reservoir, located in the southern part of the Bekaa valley, between the two Lebanese mountain chains, is the largest freshwater body in Lebanon (Figure 1, Table 1). The reservoir was constructed between 1958 and 1965 on the Litani River (170 km length) for power production and irrigation. The river inflow occurs mainly in the wet season, from October to April, while the withdrawals are much more regular in the year, which causes a large water level variation in the year, and can reach up to $30 \mathrm{~m}$ (Fadel et al., 2014b). 


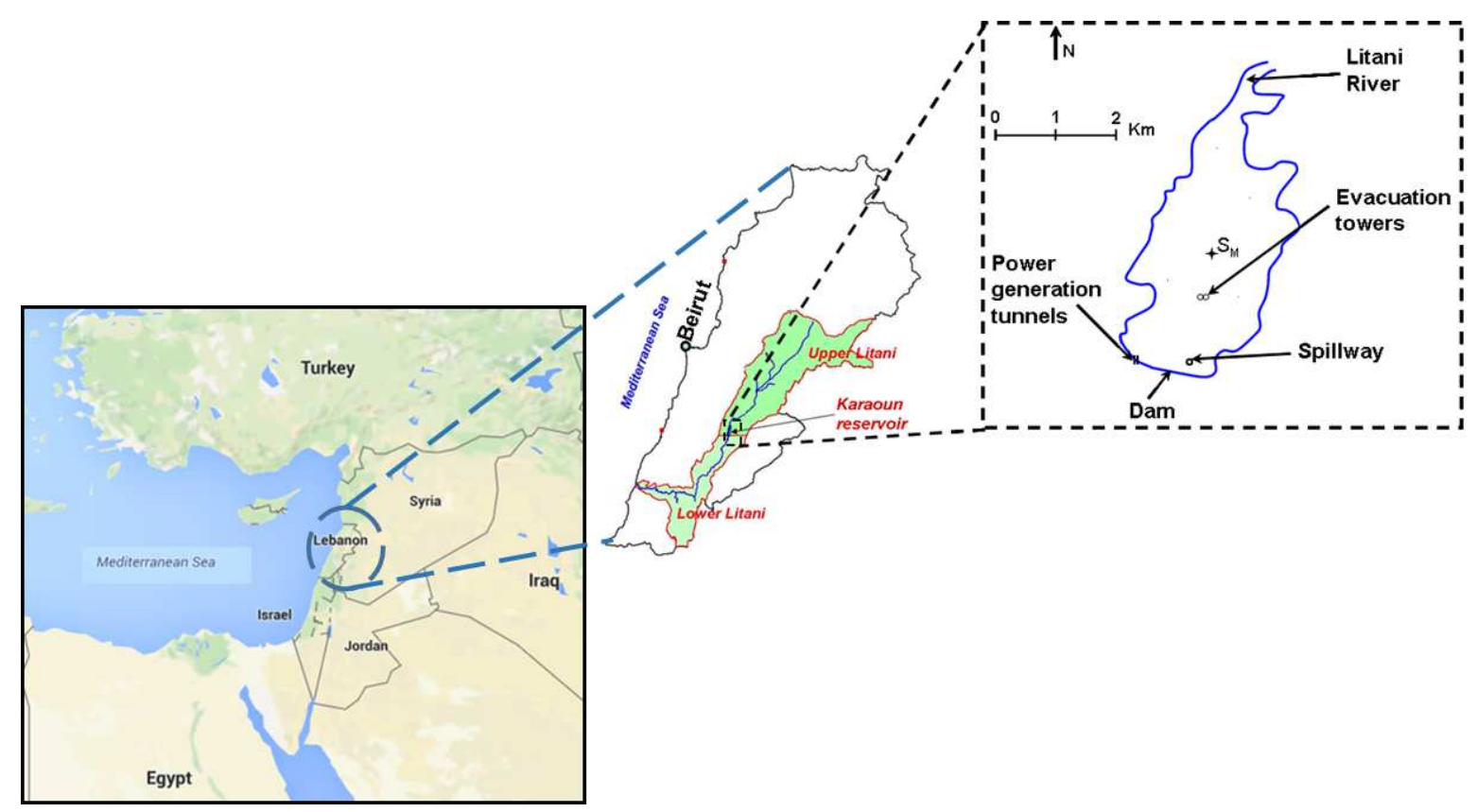

Figure 1 Karaoun Reservoir and sampling site: $S_{M}\left(3^{\circ} 34\right.$ ' 05’'N, 35 ${ }^{\circ} 41^{\prime} 44$ ''E).

Table 1 Karaoun Reservoir morphometric and hydrologic characteristics.

\begin{tabular}{|c|c|}
\hline Surface area at full capacity & $12 \mathrm{~km}^{2}$ \\
\hline Maximum storage capacity & $224 \times 10^{6} \mathrm{~m}^{3}$ \\
\hline Maximum depth & $60 \mathrm{~m}$ \\
\hline Mean depth at full capacity & $858.28 \mathrm{~m}$ above sea level \\
\hline Altitude at maximum level & $1,600 \mathrm{~km}^{2}$ \\
\hline Catchment area & 9 months (Fadel et al., 2014a) \\
\hline Mean residence time of water & \\
\hline
\end{tabular}




\subsection{Sampling procedure}

Measurements and samples were taken at the most representative point $\left(\mathrm{S}_{\mathrm{M}}\right)$, located in the middle of the lake $\left(33^{\circ} 34^{\prime} 05^{\prime} \mathrm{N}, 35^{\circ} 41^{\prime} 44^{\prime \prime} \mathrm{E}\right)$. To choose this point, the sampling of several physical-chemical parameters was performed at 6 points at different locations throughout the reservoir (north, east, south and west). The results of profiles measured at these 6 points were relatively close with a variation of about $35 \%$. The sampling point $S_{M}$ was selected as the most representative because its values were comparable to the average of the measurements taken at the 6 different locations. Campaigns were performed bi-weekly between 11:00 and 13:00. Water samples were collected at $0.5 \mathrm{~m}$ depth from May to November 2012 and at 0.5, 5 and $10 \mathrm{~m}$ depths from March to August 2013 with a vertical Niskin bottle of $2.2 \mathrm{~L}$ capacity (Wildco 1120-D42, Florida, United States). Samples were stored at $4^{\circ} \mathrm{C}$ until further processing in the laboratory. Different volumes and bottles were used for phytoplankton identification and counting, nutrient analysis and chlorophyll-a quantification.

\subsection{Physical measurements and nutrient analysis}

Transparency measurements were performed at $S_{M}$ with a Secchi disk. Measurements of dissolved oxygen concentration (in $\mathrm{mg} / \mathrm{L}$ ) were conducted at subsurface using an oxymeter (Hanna HI 9146, Woonsocket, USA).

Water temperature was measured continuously at the spillway with temperature sensors (Starmon mini, Star-Oddi, Gardabaer, Iceland) fixed on a buoy at 1, 7, 10, 13 and $16 \mathrm{~m}$ depths to monitor thermal stratification. The sensor measuring temperature range is -2 to $40{ }^{\circ} \mathrm{C}$ with an accuracy of $\pm 0.05^{\circ} \mathrm{C}$.

Subsamples used for the analysis of nutrients (total phosphorus, orthophosphate, nitrate, and ammonium) were preserved at $4{ }^{\circ} \mathrm{C}$ after addition of $2 \mathrm{~mL}$ of $18 \mathrm{M} \mathrm{H}_{2} \mathrm{SO}_{4}$. Soluble phosphorus (orthophosphate), nitrate, and ammonium subsamples were then filtered through a $0.45 \mu \mathrm{m}$ cellulose acetate filter (MF-Millipore, HAWP04700, Utah, United States).

Nitrate and ammonium concentrations were then estimated by colorimetry with a photometer (Palintest Photometer 7000se, Gateshead, England). Total phosphorus and orthophosphate concentrations were determined at $880 \mathrm{~nm}$ by UV/visible spectrophotometry (Thermospectronic, LaboTech, Beirut, Lebanon) using the colorimetric ascorbic acid method (EPA Standard Method 365.3, Washington, United States). The quantification range for nitrate nitrogen was $0.1-30 \mathrm{mg} \mathrm{N} \mathrm{L}^{-1}$, for ammonium nitrogen $0.1-12 \mathrm{mg} \mathrm{N} \mathrm{L}^{-1}$, and for phosphorus 0.001 to $1.2 \mathrm{mg} \mathrm{P} \mathrm{L}^{-1}$.

\subsection{Phytoplankton analysis}

The phytoplankton species were determined on the sampling day according to taxonomic keys based on cell structure and dimensions, colony morphology, and mucilage characteristics (Komárek and Anagnostidis, 1999, 2005). Microscopic identifications and enumeration were carried out under a phase contrast microscope (Nikon TE200, Nikon, Melville, New York, USA). The subsamples used for counting were fixed by formaldehyde ( $4 \%$ formaldehyde of sample volume) and preserved at $4{ }^{\circ} \mathrm{C}$. Phytoplankton counting was carried out under a $\times 40$ 
objective using Nageotte chamber that accepts $100 \mu \mathrm{L}$ on 40 bands. The number of bands counted depended on sample concentration. Each subsample was counted on triplicate.

Total biovolumes of each phytoplankton species was calculated by multiplying the counted number of cells per millilitre by the average biovolume of a cell of that species. Cell biovolumes of each species were calculated according to the most suitable geometric models (Sun and Liu, 2003).

Chlorophyll-a quantification, used to estimate total phytoplankton biomass, was carried out according to Lorenzen method (Lorenzen, 1967). A duplicate of each sample was filtered using Whatman GF/C filters that were then kept frozen at $-20{ }^{\circ} \mathrm{C}$ for $16 \mathrm{~h}$. Chlorophyll a was extracted from these filters in $90 \%$ acetone by ultrasonication and agitation. The extracts were centrifuged at $3500 \mathrm{rpm}$ for $10 \mathrm{~min}$ to reduce the turbidity. About $2 \mathrm{~mL}$ were used for chlorophyll-a quantification by spectrophotometry, then a correction was performed by adding $60 \mu \mathrm{L}$ of $0.1 \mathrm{M} \mathrm{HCl}$ to these $2 \mathrm{~mL}$ to measure the amount of chlorophyll-a degradation product, pheophytin-a.

\subsection{Zooplankton analysis}

Zooplankton samples were collected using a net with a mesh size of $100 \mu \mathrm{m}$ by lowering the nets to approximately two meter below the water surface. Samples were stored in 5\% formalin. Major taxonomic groups that were identified and enumerated according to Stemberger (1979), Smith and Fernando, (1978), and Lynne (2004).

\subsection{Meteorological and hydrological data}

Solar radiation were obtained from Tal-Amara meteorological station of the Lebanese

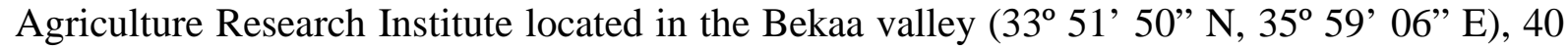
$\mathrm{km}$ North of Karaoun Reservoir. Weekly water levels measured on a graduated scale at the spillway were provided by the Litani River Authority, responsible for the management of the reservoir. The main withdrawal is through hydropower canals and irrigation canals; the outflow volume is measured directly on a canal transect. The main reservoir inflow is from the Litani River. Since it was not measured in 2012 and 2013, it was estimated by difference from the water level and the measured withdrawals. This method underestimates the inflow rate when the reservoir is full, since overflows through the spillway are not counted. More details about the reservoir functioning and hydrology are presented in (Fadel et al., 2014a).

\section{Results}

\subsection{Hydrological conditions}

The evolution of the water level and the inflow and outflow rates in 2012 and 2013 in Karaoun Reservoir is presented in Figure 2. The reservoir reached its maximum capacity of $224 \times 10^{6} \mathrm{~m}^{3}(858.28 \mathrm{~m}$ above sea level) in both 2012 and 2013 . The total outflow rate was rather regular except during high waters and ranged from 0 to $40 \mathrm{~m}^{3} \cdot \mathrm{s}^{-1}$ (Figure 2c). Withdrawals from Karaoun Reservoir occur through three outlets: 1) the Markabi hydropower tunnels, that collect about $98 \%$ of the total outflow except for the periods in which the evacuation tunnels are used, 2) the main pumping station (MPS) that is used for irrigation 
through Canal 900, that collects less than $2 \%$ of the total outflow throughout the dry season from April to October or November, 3) the evacuation tunnels that are seldom used; they were not used in 2013 but they were operated between the mid of March and April 2012 because of high inflow volumes from the Litani River (Figure 2c) while the reservoir was full.
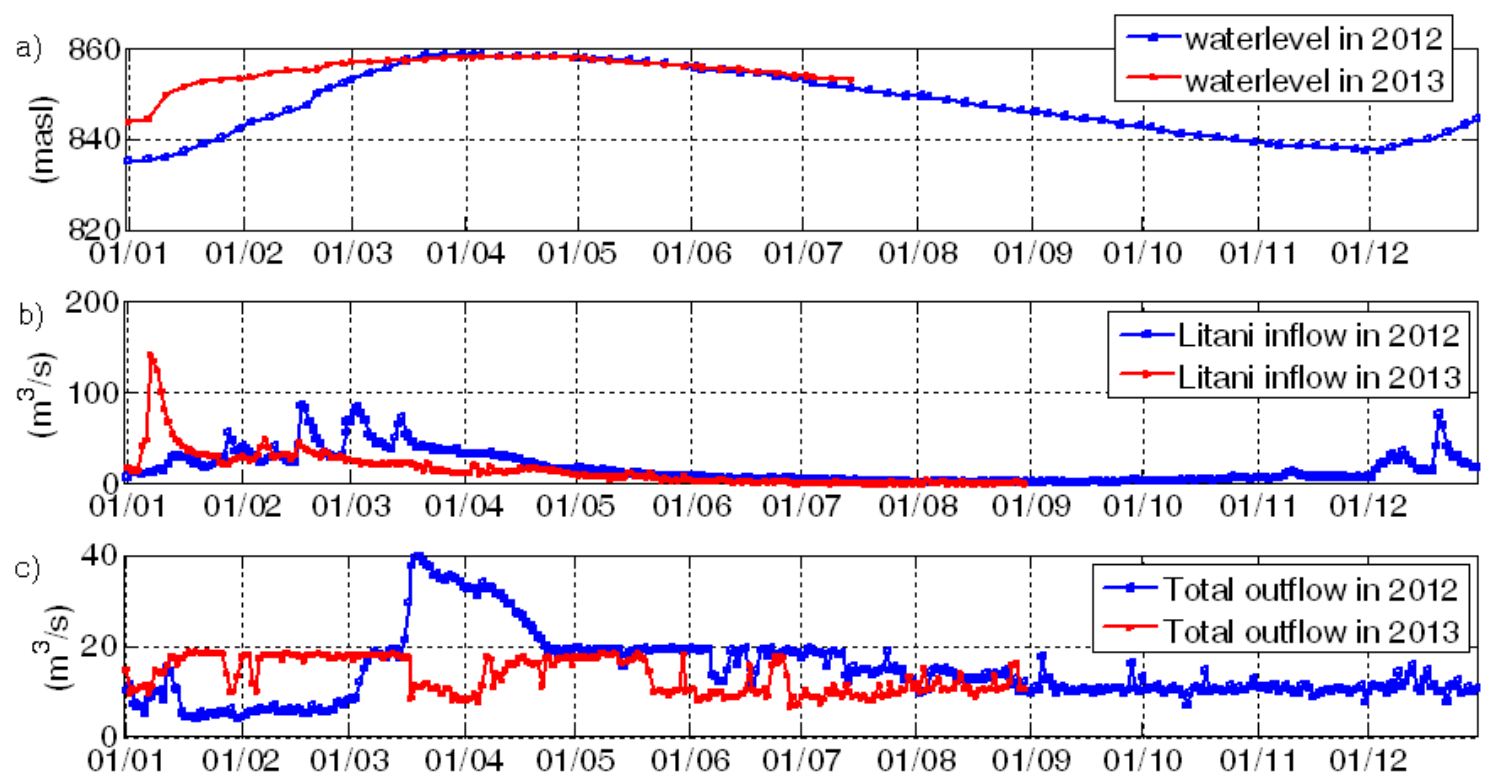

Figure 2 a) measured water level, b) inflow computed from outflow rate and water level and c) outflow rate at Karaoun Reservoir in 2012 and 2013

The total inflow volume of Litani River to Karaoun reservoir between January and August was $407.10^{6} \mathrm{~m}^{3}$ for the year 2012 and $320.10^{6} \mathrm{~m}^{3}$ for the year 2013. Higher inflow rates in January 2013 (Figure 2b) led to higher water levels between January and March 2013 (Figure 2a). Between mid-March and July the water level was comparable in both years but the withdrawal volume was smaller in 2013.

\subsection{Physical-chemical parameters}

Water transparency was low; it ranged between 0.5 and $2.5 \mathrm{~m}$ (Figure 3c) and showed little variation throughout the study period. Dissolved oxygen ranged from 4 to $14 \mathrm{mg} / \mathrm{l}$ (oversaturation by 55\%), at both measured depths 0.4 and $4 \mathrm{~m}$ (Figure 3d). This oversaturation was not correlated to phytoplankton concentrations. Oversaturation was observed for both low and high phytoplankton biomasses (Figure 3e). The vertical dissolved oxygen profile performed in 18 August (Figure 4) showed anoxia at $20 \mathrm{~m}$ and a drop in oxygen concentration between 10 and $15 \mathrm{~m}$ representing the oxycline depth during the summer season. Specific conductivity in Karaoun Reservoir was only measured twice during the study period. It ranged between 405 and $490 \mu \mathrm{S} / \mathrm{cm}$. Subsurface chlorophyll-a concentration ranged between $6 \mu \mathrm{g} . \mathrm{L}^{-1}$ (20 November) and $226 \mu \mathrm{g} . \mathrm{L}^{-1}(07$ November) in 2012 (Figure 3e). It also reached a comparable maximum concentration of $214 \mu \mathrm{g} . \mathrm{L}^{-1}$ (08 July) in 2013 (Figure 3e). 


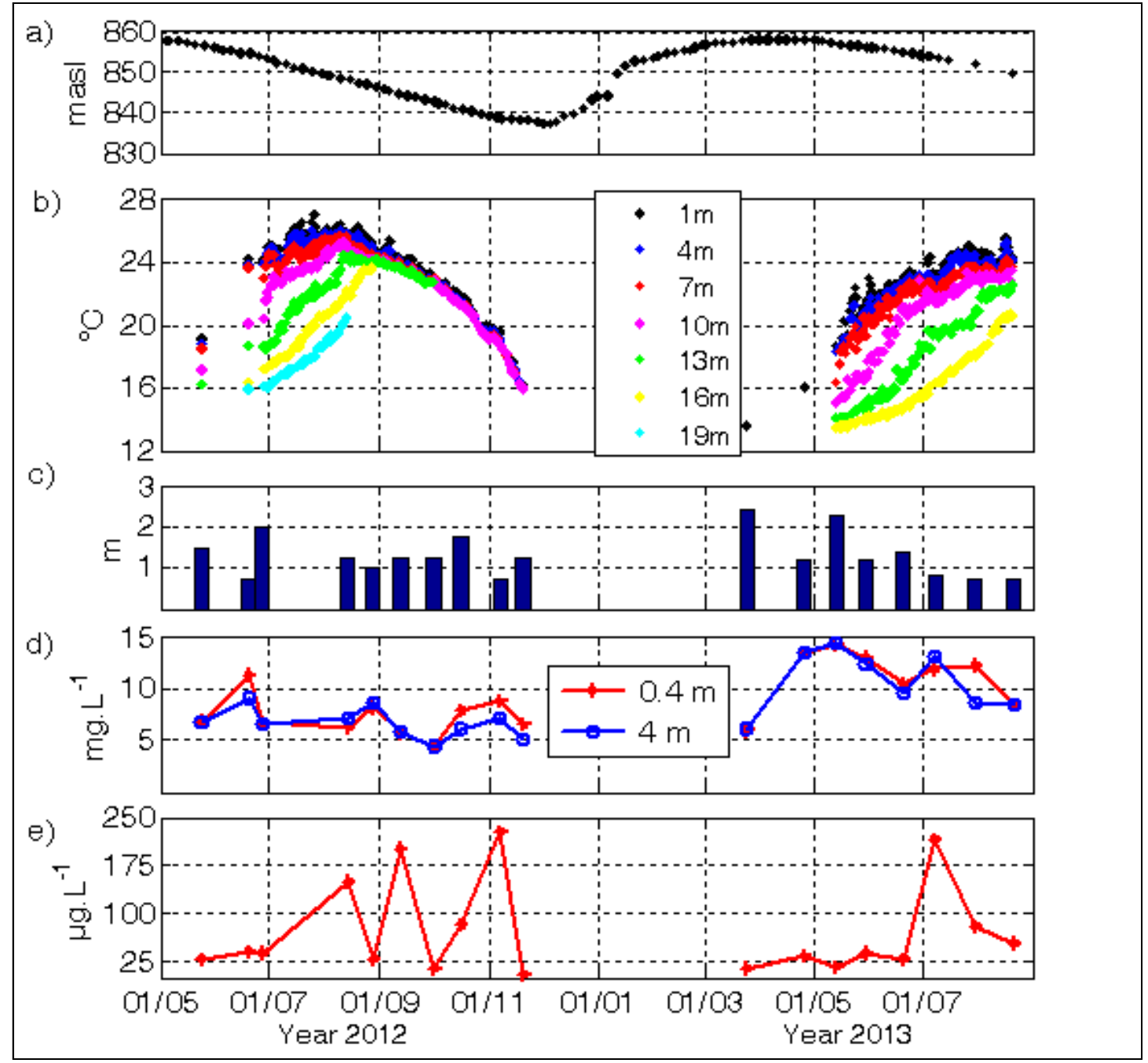

Figure 3 Variation of a) water level, b) water temperature, c) transparency, d) dissolved oxygen concentration at 0.4 and 4-m depths and e) subsurface chlorophyll-a concentration at $S_{M}$ in Karaoun Reservoir in 2012 and 2013

Karaoun Reservoir was at its full capacity in mid May 2012 (Figure 3a). Due to continuous withdrawals, the water level decreased by $22 \mathrm{~m}$ until mid-November 2012 . Water level then increased in winter to reach its maximum capacity in May 2013 where an overflow occurred for one week. Surface water temperature showed high seasonal variations at Karaoun Reservoir during the study period (Figure $3 b$ ). The reservoir was warm monomictic in both 2012 and 2013. Thermal stratification was already established in May, strong persistent stratification continued between June and July, then stratification started to debilitate at the end of July. The water temperature difference between the 1 and 16-m depths ranged from 0 ${ }^{\circ} \mathrm{C}$ in November and December 2012 to more than $10^{\circ} \mathrm{C}$ in July 2012 and 2013 (Figure 3b). 


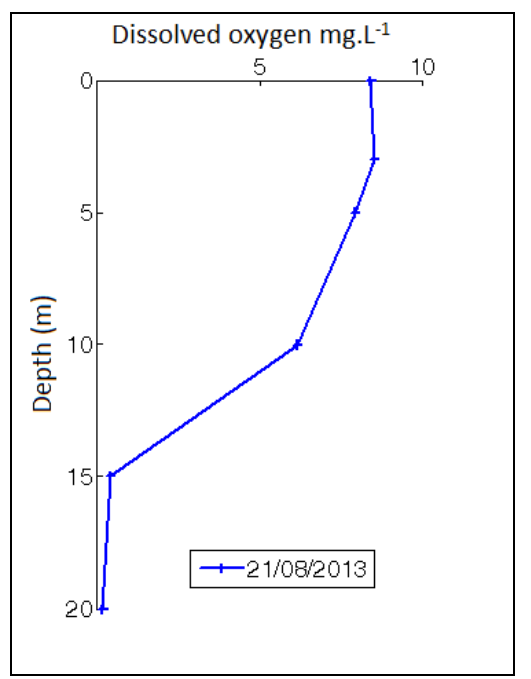

Figure 4 Vertical profile of dissolved oxygen at Karaoun Reservoir on 21 August 2013.

Ammonium concentration was always below detection level while nitrate concentration reached a maximum of $0.47 \mathrm{mg} \mathrm{N} . \mathrm{L}^{-1}$ (on 16 October 2012) and a minimum of $0.02 \mathrm{mg} \mathrm{N} . \mathrm{L}^{-1}$ (on 01 October 2012) (Table 2).

Table 2 Subsurface nutrient measurements at Karaoun Reservoir in 2012, (-: not measured).

\begin{tabular}{|c|c|c|c|}
\hline Date & $\begin{array}{c}\mathrm{N}^{-N_{3}} \\
(\mathrm{mg} \mathrm{N} / \mathrm{L})\end{array}$ & $\begin{array}{c}\mathrm{P}^{-\mathrm{PO}_{4}} \\
(\mathrm{mg} \mathrm{P} / \mathrm{L})\end{array}$ & $\begin{array}{c}\text { Total P } \\
(\mathrm{mg} \mathrm{P} / \mathrm{L})\end{array}$ \\
\hline $\begin{array}{c}07 / 06 / 201 \\
2\end{array}$ & - & $4.7 \times 10^{-3}$ & 0.042 \\
\hline $\begin{array}{c}19 / 06 / 201 \\
2\end{array}$ & - & $1.19 \times 10^{-2}$ & 0.034 \\
\hline $\begin{array}{c}15 / 07 / 201 \\
2\end{array}$ & 0.16 & - & - \\
\hline $\begin{array}{c}14 / 08 / 201 \\
2\end{array}$ & 0.05 & - & 0.039 \\
\hline $\begin{array}{c}28 / 08 / 201 \\
2\end{array}$ & - & $2.34 \times 10^{-3}$ & 0.035 \\
\hline $\begin{array}{c}12 / 09 / 201 \\
2\end{array}$ & 0.05 & $4.76 \times 10^{-3}$ & 0.149 \\
\hline $\begin{array}{c}01 / 10 / 201 \\
2\end{array}$ & 0.04 & $2.71 \times 10^{-3}$ & 0.020 \\
\hline $\begin{array}{c}16 / 10 / 201 \\
2\end{array}$ & 0.47 & $1.19 \times 10^{-3}$ & 0.025 \\
\hline $\begin{array}{c}07 / 11 / 201 \\
2\end{array}$ & 0.02 & $1.19 \times 10^{-3}$ & 0.132 \\
\hline $\begin{array}{c}20 / 11 / 201 \\
2\end{array}$ & 0.03 & $2.67 \times 10^{-3}$ & 0.028 \\
\hline
\end{tabular}

In 2013, ammonium concentration always remained below detection level. At all measurement depths and during the whole monitored period, nitrate concentration did not exceed $0.2 \mathrm{mg} \mathrm{N} . \mathrm{L}^{-1}$ (Figure 5). At the beginning of the 2013 campaigns on $25 \mathrm{March}$, the 
nitrate profile showed higher concentrations in the epilimnion than in the hypolimnion. Nitrate concentrations then decreased gradually at the surface and became higher in the hypolimnion by the end of the study period in 2013 .

The total phosphorus concentration reached a maximum of $0.15 \mathrm{mg} \mathrm{P.L} \mathrm{L}^{-1}$ (on 12 September

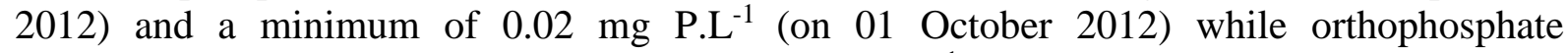

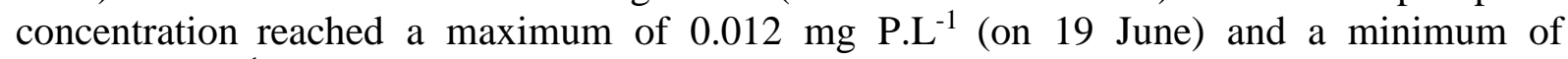
$0.001 \mathrm{mg} \mathrm{P.L^{-1 }}$ (on 16 October and 07 November 2012, Table 2).

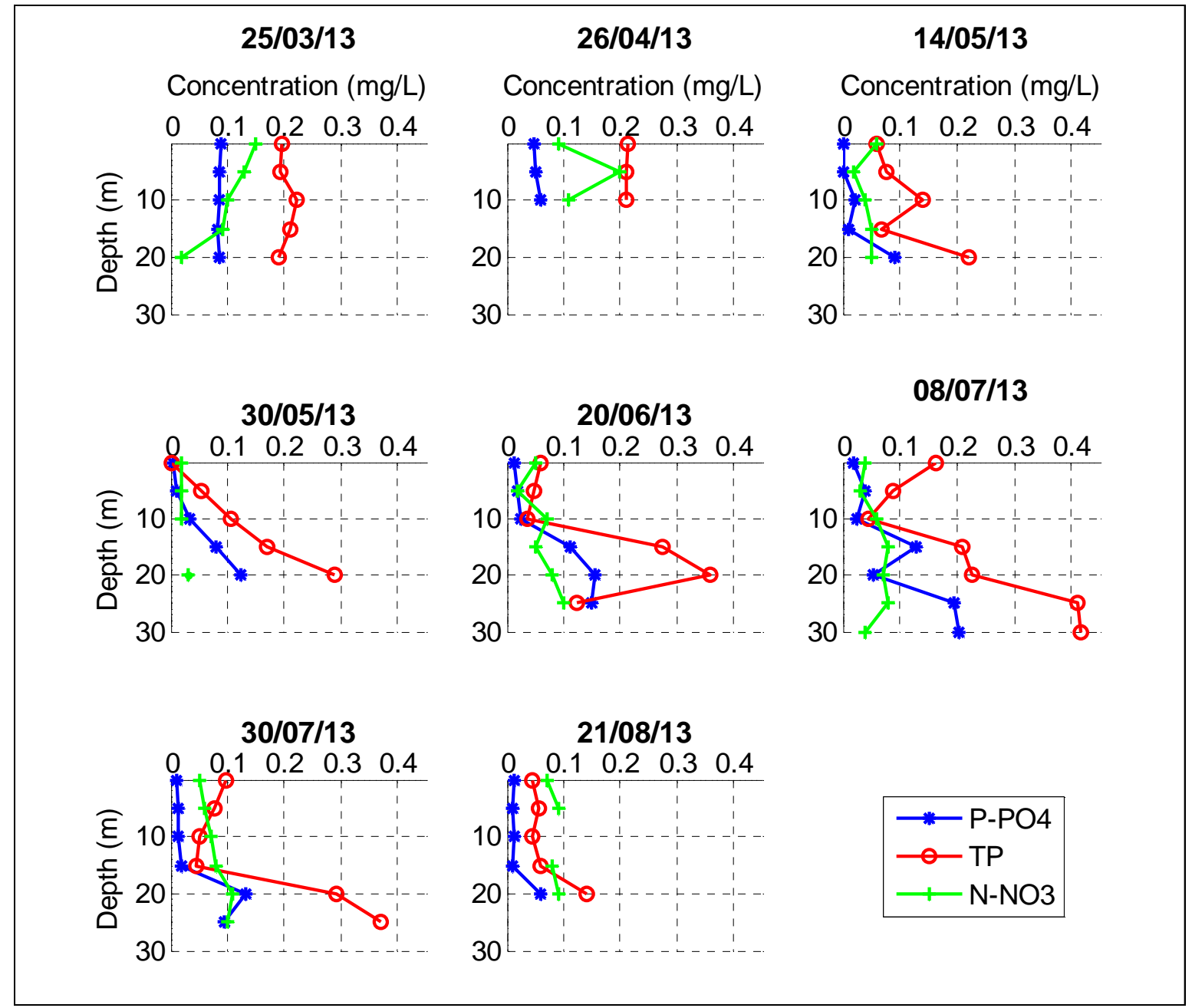

Figure 5 Vertical profiles of orthophosphate $\left(\mathrm{P}-\mathrm{PO}_{4}\right)$, total phosphorus (TP) and nitrate $\left(\mathrm{N}-\mathrm{NO}_{3}\right)$ concentrations at $S_{M}$ in Karaoun Reservoir in 2013.

In 2013, the maximum values of both total phosphorus and orthophosphate concentrations were recorded near the bottom of the reservoir (Figure 5). Through different depths in the water column and during the whole monitored period, total phosphorus reached maxima of $0.42 \mathrm{mg} \mathrm{P.L} \mathrm{L}^{-1}$ (08 July 2013, $30 \mathrm{~m}$ at $\mathrm{S}_{\mathrm{M}}$ ) and minima of $0 \mathrm{mg} \mathrm{P.L} \mathrm{L}^{-1}$ (30 May 2013, subsurface at $\mathrm{S}_{\mathrm{M}}$ ) while orthophosphate reached maxima of $0.204 \mathrm{mg} \mathrm{P.L} \mathrm{L}^{-1}$ (08 July 2013, $30 \mathrm{~m}$ at $\mathrm{S}_{\mathrm{M}}$ ) and minima under detection limit (30 May 2013, subsurface at $S_{M}$ ). The relative vertical distribution of orthophosphate paralleled the distribution of total phosphorus within the water column (Figure 5). At the beginning of the survey in March 2013, both total phosphorus (TP) 
and orthophosphate $\left(\mathrm{PO}_{4}\right)$ vertical profiles were homogeneous through the water column. Phosphorus concentrations decreased gradually in the top $10 \mathrm{~m}$ to below $0.1 \mathrm{mg} \mathrm{P.L}{ }^{-1}$ in May 2013, and stayed lower than $0.1 \mathrm{mg} \mathrm{P.L}{ }^{-1}$ until the end of the survey except for the end of May 2013 and beginning of July 2013 where an increase in total phosphorus concentration at the subsurface occurred. At the end of the survey in August 2013, phosphorus concentration in the top $20 \mathrm{~m}$ reached its lowest values.

\subsection{Phytoplankton composition, biovolumes and seasonal succession}

The phytoplankton community structure varied greatly from May to November 2012 and March to August 2013, the period when phytoplankton cell viability was examined. A total of 30 phytoplankton species were identified (Table 3 ) in the water samples examined throughout both years. Chlorophytes contributed with the highest number of species (11) followed by Cyanobacteria (10), Bacillariophyta (8) and Dinophyta (1).

Throughout the study period, the total biovolume ranged from 0.3 to $12.4 \mathrm{~mm}^{3} \mathrm{~L}^{-1}$ (Figure 6e and Figure 7). The lowest total biovolume was recorded on March 2013 while the highest total biovolumes in summer and autumn, in October 2012 during cyanobacterium Aphanizomenon ovalisporum bloom at $12.4 \mathrm{~mm}^{3} \mathrm{~L}^{-1}$, November 2012 during dinophytum Ceratium hirundinella bloom at $11.9 \mathrm{~mm}^{3} \mathrm{~L}^{-1}$ (Figure 6) and July 2013 during cyanobacterium Microcystis aeruginosa bloom at $12.3 \mathrm{~mm}^{3} \mathrm{~L}^{-1}$.

The four phytoplankton groups were detected in both monitored years, but the pattern was not the same. Some groups were detected earlier but as an overall: Chlorophyta dominated in spring, cyanobacteria dominated in summer and early autumn, Dinophyta dominated in late autumn and diatoms occurred in low biovolumes in spring, summer and autumn.

Diatoms were present in low biovolumes throughout the study period; this group was dominated by Melosira varians and Aulacoseira granulata with a very different pattern in 2012 and 2013. Aulacoseira granulata occurred in both mixed and stratified water columns. Melosira varians was detected only at the end of April 2013 in low biovolume in a stratified water column, with high irradiance, high water level and water temperature of $16{ }^{\circ} \mathrm{C}$. However, it declined after 2 weeks at the beginning of May 2013. Aulacoseira granulata was also detected at the end of April 2013 and it was detected frequently in low biovolumes between May and November 2012 in a wide range of water temperature, irradiance, nutrient availability, thermal stratification and water level conditions (Figure 6). 


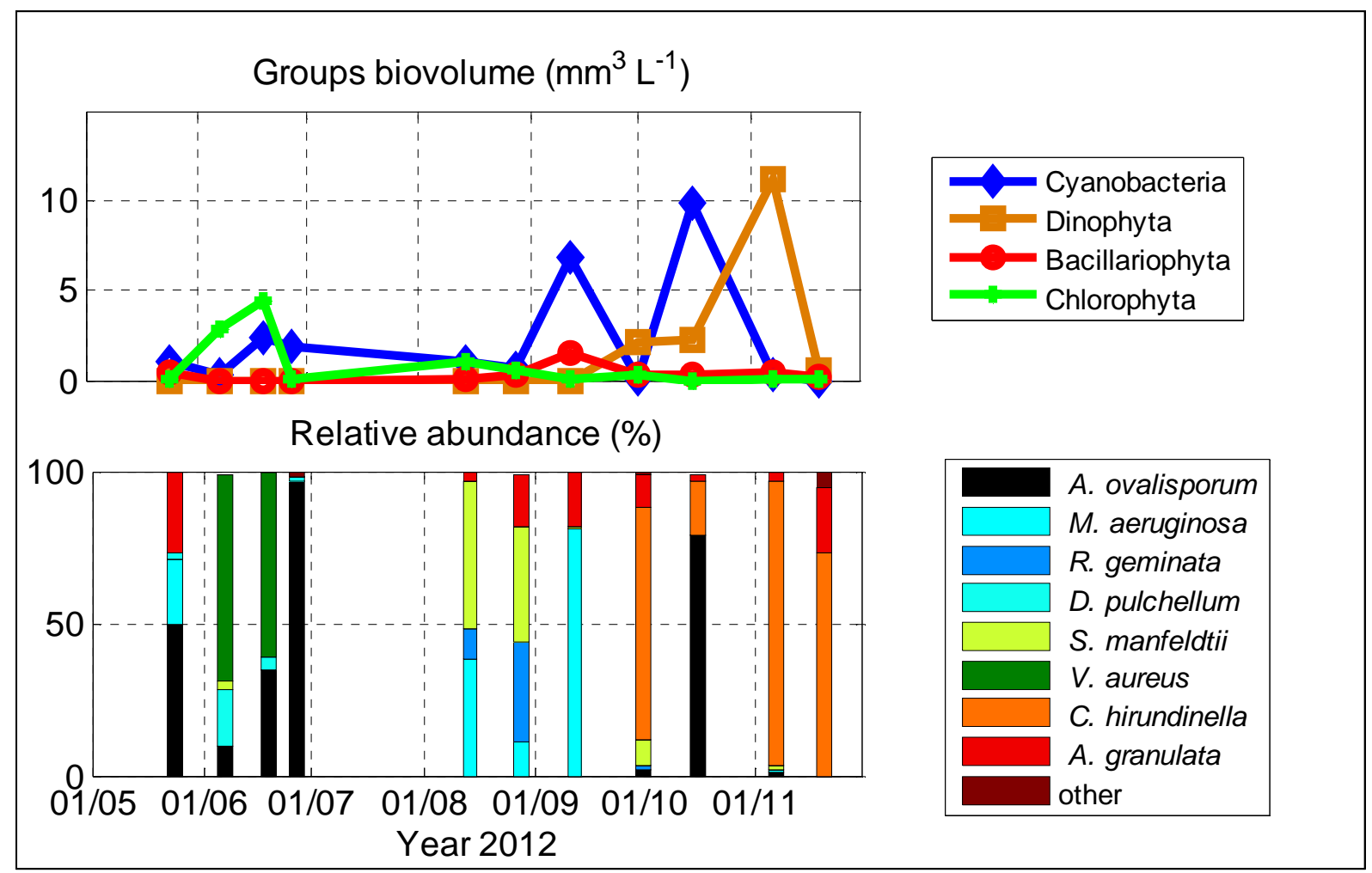

Figure 6 Biovolumes of phytoplankton groups and relative abundance of phytoplankton species at the subsurface in Karaoun Reservoir in 2012.

In 2012 and 2013, Chlorophyta were dominated by Botryococcus braunii, Dictyosphaerium pulchellum, Volvox aureus, Staurastrum manfeldtii and Coelastrum microporum. Only 3 species were detected in subsurface samples of 2012 (Dictyosphaerium pulchellum, Volvox aureus, Staurastrum manfeldtii). Volvox aureus dominated in June 2012 with the presence of Dictyosphaerium pulchellum in high irradiance, a stratified water column, a high water level and a water temperature of $24{ }^{\circ} \mathrm{C}$. Staurastrum manfeldtii dominated in August with the cyanobacterium Microcystis aeruginosa in lower irradiance and water level, in a thermal stratification period with awater temperature of $26^{\circ} \mathrm{C}$ (Figure 6).

In 2013, Volvox aureus was detected earlier at the end of April, not in similar conditions as in 2012, water temperature was below $18{ }^{\circ} \mathrm{C}$. Botryococcus braunii and Coelastrum microporum were detected for the first time in Karaoun Reservoir and dominated at the beginning of May in high irradiance, a stratified water column, with a high water level and a water temperature of $19{ }^{\circ} \mathrm{C}$. After the increase of water temperature to $23{ }^{\circ} \mathrm{C}$ and as well thermal stratification at the end of May, Botryococcus braunii and high biovolume Coelastrum microporum were replaced by Staurastrum manfeldtii that dominated and also occurred in low biovolumes in June. Dictyosphaerium pulchellum, Kirchneriella obesa, Desmodesmus communis, Haematococcus pluvialis, Closterium acutum, Pediastrum duplex, Pediastrum boryanum were also detected in Karaoun Reservoir in 2013 but in low biovolumes. 
a)

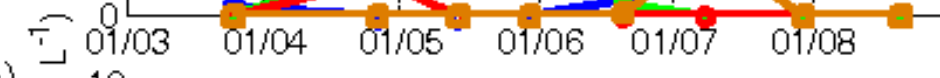

b)

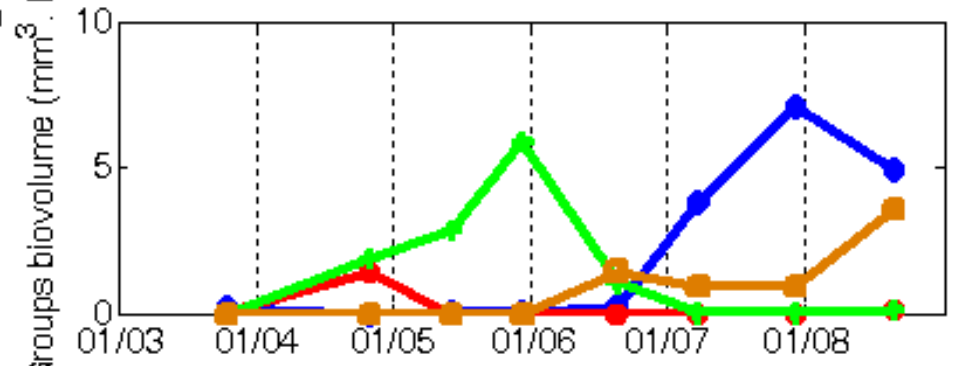

c)

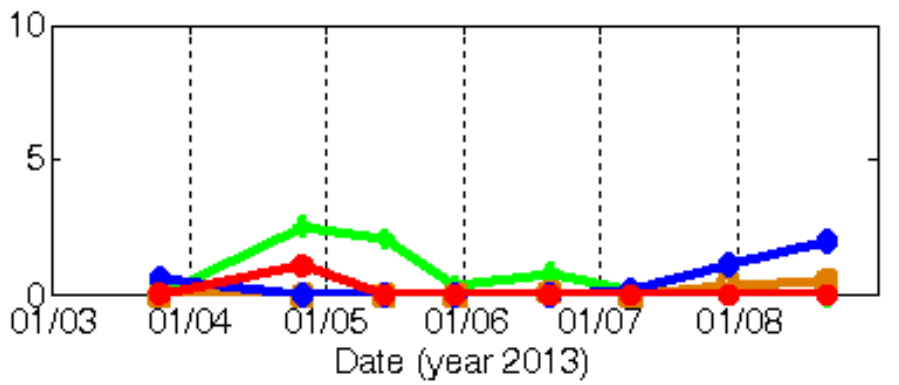

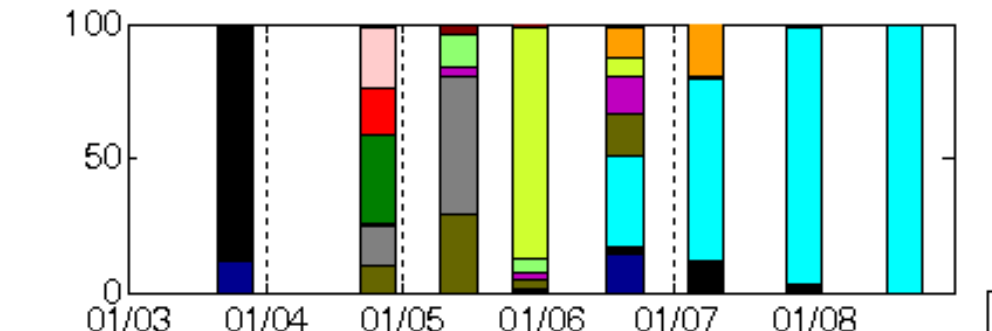
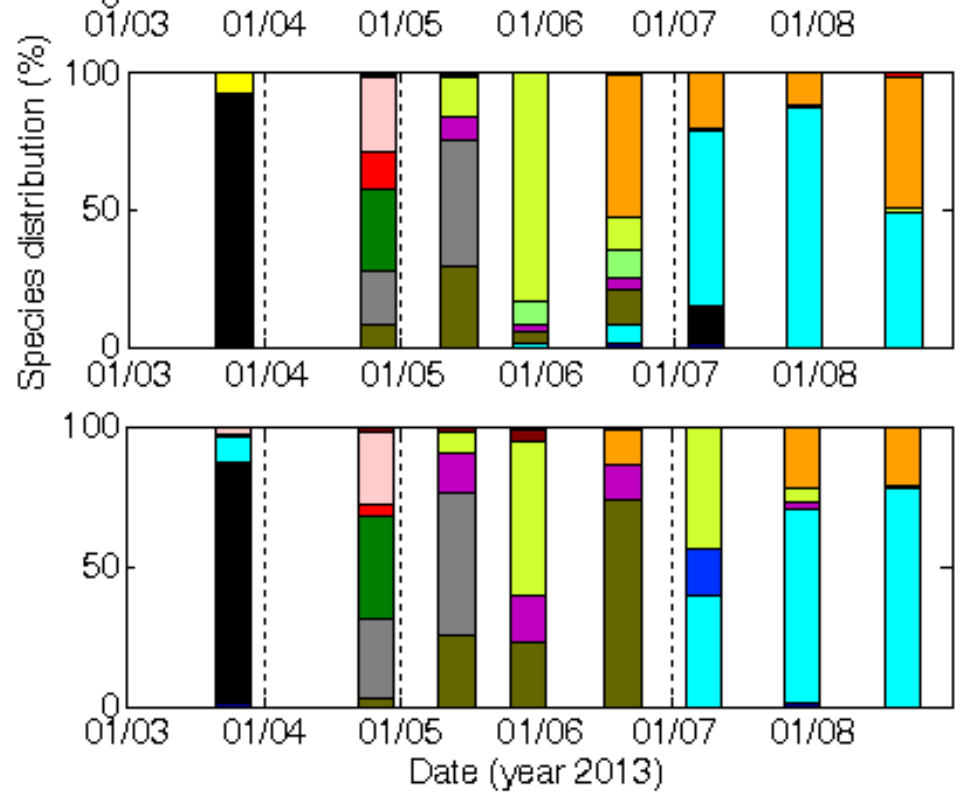

- Cyanobacteria - Chlorophyta

Bacillariophyta

Dinophyta

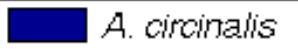
A ovalisporum $M$ aeruginosa R. geminata

C. microporum

B. braunii

D. pulchellum

P.duplex

S. manfeidtii

V.aureus

C. hirundinella

A. granulata

F. wha

M.varians

Others

Figure 7 Variation of the biovolumes of phytoplankton groups and their species distribution at a) subsurface, b) $5 \mathrm{~m}$ and c) $10 \mathrm{~m}$. 
1 Cyanobacteria group was dominated by Aphanizomenon ovalisporum and Microcystis 2 aeruginosa. Aphanizomenon ovalisporum occurred in low biovolumes with Chlorophyta and 3 diatoms between the end of May and the end of June during periods of high irradiance and 4 water level, thermal stratification and surface water temperature ranging between 18 and 25 $5{ }^{\circ} \mathrm{C}$. Aphanizomenon ovalisporum was then replaced by another subsurface bloom-forming 6 cyanobacterium, Microcystis aeruginosa, that developed populations in August 2012 7 (coinciding with Staurastrum manfeldtii) and had its biovolume peak in September 2012 in a period of lower irradiance and water level, weaker stratification and subsurface water temperature of $25{ }^{\circ} \mathrm{C}$. In October 2012, after the decline of Microcystis aeruginosa, Aphanizomenon ovalisporum emerged as the dominant genus and had its biovolume peak. Then the decline in the Aphanizomenon ovalisporum population coincided with the development of Ceratium hirundinella.

In 2012, Anabaena circinalis were not detected; it was first detected in low biovolumes in March 2013 (coinciding with Aphanizomenon ovalisporum that contained akinetes, Figure 6) and then in June 2013 (coinciding with Microcystis aeruginosa, Chlorophyta and Ceratium hirundinella).

Microcystis aeruginosa was most prevalent at subsurface and was detected earlier in June and 18 had its biovolume peak at the end of July in a stratified water column, with a high water level, high solar irradiance and temperature ranging between 22 and $24{ }^{\circ} \mathrm{C}$.

Ceratium hirundinella was the only dinoflagellate observed in Karaoun Reservoir in 2012 and 2013. Biovolume peaks of Ceratium hirundinella occurred at the beginning of November 2012 during destratified water column, low water level, low irradiance and water temperature of $20{ }^{\circ} \mathrm{C}$. The increases in biovolume of Ceratium hirundinella between October and November 2012 coincided with a decrease in temperature and irradiance. Ceratium hirundinella was then detected in June, July and August 2013 in a stratified water column, with the highest irradiance $\left(240 \mathrm{~W} \cdot \mathrm{m}^{-2}\right)$, a high water level and high water temperatures ranging between 20 and $25{ }^{\circ} \mathrm{C}$. However, it was detected in small biovolumes during this period and was most prevalent at $5 \mathrm{~m}$ depth. 



\begin{tabular}{|c|c|c|c|}
\hline \multicolumn{1}{|c|}{ Cyanobacteria } & Chlorophyta & \multicolumn{2}{|c|}{ Diatoms } \\
\hline Oscillatoria tenuis & Kirchneriella obesa & Diatoma vulgare \\
Microcystis aeruginosa & Dictyosphaerium pulchellum & Fragilaria ulna \\
Microcystis ichthyoblabe & Desmodesmus communis & Navicula menisculus & Ceratium hirundinella \\
Microcystis viridis & Botryococcus braunii & Navicula cryptocephala & Cymatopleura elliptica \\
Microcystis botrys & Haematococcus pluvialis & Nitzschia gracilis & Melosira varians \\
Aphanizomenon ovalisporum & Closterium acutum & Aulacoseira granulata & \\
Anabaena spiroides & Coelastrum microporum & & \\
Anabaena circinalis & Pediastrum duplex & Volvox aureus & \\
Radiocystis geminata & Staurastrum manfeldtii & & \\
Pilgeria brasiliensis & Pediastrum boryanum & & \\
\hline
\end{tabular}




\subsection{Zooplankton community}

Zooplankton species dominated in Karaoun Reservoir when the cyanobacterial biomass was low. Nine zooplankton species were found in the lake in 2012 and 2013: two rotifers (Asplanchna periodonta and Keratella cochlearis), three cladocerans (Chydorus sphaericus, Daphnia magna and Moina rectirostris) and four copepods (Eudiaptomus drichii, Mesocyclops ogunnus, Mr. leuckarti and cyclopoid nauplii). No studies on the zooplankton microfauna have been done in Lebanon so far. This list is not exhaustive, more frequent monitoring must be done in the coming years to close the gap and understand the fluctuations of the zooplankton community.

\section{Discussion}

Diatoms in Karaoun Reservoir were rare, not only in terms of biomass, but also in terms of species number, contributing to low biovolumes during the study period. The reservoir was not monitored in winter, a season that can be favourable for the growth of this group. There was no limitation in phosphorus concentration in spring 2013. Silica limitation is possible but since it was not measured it cannot be confirmed. During persistent thermal stratification Aulacoseira species tend to sink out of the euphotic zone at a speed of $0.95 \mathrm{~m}^{-\mathrm{d}^{-1}}$ (Sherman et al., 1998). In spring and summer, Karaoun Reservoir was stratified; this can partially explain why diatoms biomass which was mainly represented by Aulacoseira granulata was low at the top $10 \mathrm{~m}$ in 2012 and 2013.

Green algae blooms occurred in late spring at temperatures lower than $22{ }^{\circ} \mathrm{C}$ and high phosphorus concentrations in 2013. Thermal stratification in Karaoun Reservoir was already established in May 2013. This might explain the dominance of vertically migrating green algae like Botryococcus braunii that becomes buoyant by producing and accumulating oil (Niehaus et al., 2011; Weiss et al., 2012) and large colonies of Volvox aureus that can rise by $3.6 \mathrm{~m}$ in one hour (Sommer and Gliwicz, 1986). In 2013, green algae were able to dominate the reservoir in spring, for two months (April and May 2013) taking advantage of nutrient availability and favourable water temperature. At the end of May nutrient concentration decreased, most probably due to its consumption by green algae and a decrease in the Litani River inflow, the main nutrient influx to Karaoun Reservoir (Fadel et al., 2014a). Nutrient limitation together with the increase in water temperature could have resulted in the decline of green algae and their replacement by cyanobacteria.

In the catchment of Karaoun Reservoir, there were at the time of the study one million habitants, $570 \mathrm{~km}^{2}$ of cultivated farmlands and several industries, mostly food, paper, tanning, plastic, cosmetic and detergent industries (Arif, 2013). This deteriorates the water quality of Karaoun Reservoir through agricultural effluents (pesticides and fertilizers), untreated industrial and municipal wastewaters, and solid and liquid wastes dumped into the Litani River (ELARD, 2011). In Summer, about $1.3 \mathrm{mg} / \mathrm{L}$ of $\mathrm{NO}_{3}, 0.7 \mathrm{mg} / \mathrm{L}$ of $\mathrm{NH}_{3}$, and $1.2 \mathrm{mg} / \mathrm{L}$ of $\mathrm{PO}_{4}$ enter Karaoun Reservoir through Litani River (USAID, 2012b). Wetland systems were designed to remove waste water loads coming from the watershed before they enter Karaoun reservoir (USAID, 2012a). The removal efficiency is 10 to $20 \%$ of total wastewater loads. Nutrient removal in winter is less effective due to the heavier loading of nutrients after storm events and the negative effect of low temperatures on microbial activity that reduces nitrogen levels (USAID, 2012b). These contamination sources along the Litani River and its 
tributaries are the main causes of the high nutrient concentrations in Karaoun Reservoir leading to algal blooms.

Results of 2012 -2013 campaigns showed that buoyant cyanobacteria (Aphanizomenon ovalisporum and Microcystis aeruginosa) dominated Karaoun Reservoir between late spring and early autumn. Environmental conditions and their physiology allow them to dominate on other phytoplankton groups in Karaoun Reservoir. Unlike diatoms which tend to sink during stratification (Huisman et al., 2004), positively buoyant cyanobacteria like Aphanizomenon ovalisporum and Microcystis aeruginosa can regulate their location in the water column, floating upwards during weak or moderate mixing (Reynolds, 2006b).

The water level decreases continuously from the beginning of May (the reservoir was full) until the end of December where the reservoir volume usually reaches $25 \%$ of the capacity. The decrease in water volume in the reservoir is mainly due to withdrawals for hydro-power generation. However, these withdrawals do not destroy the stable thermal stratification. Rainfall on the reservoir catchment has an important role in disrupting thermal stratification due to washout (Domis et al., 2013), but it is not the case of Karaoun. Precipitation events in Karaoun Reservoir become rare after the end of April. Segura et al. (2013) showed that the competitive ability of large cyanobacteria with gas vesicles was highest under low flushing rates. Romo et al. (2013) suggested that longer water residence time in the dry season increased total Microcystis aeruginosa populations and microcystin production in the lake water. The decrease in rainfall in Mediterranean lakes decreases the flushing rates and increases the dominance of cyanobacteria.

Aphanizomenon ovalisporum blooms develop at the beginning of spring and autumn while Microcystis aeruginosa blooms at higher temperature in summer. Aphanizomenon ovalisporum optimal temperature is lower than that of Microcystis aeruginosa (optimal temperature: $28-32{ }^{\circ} \mathrm{C}$; minimal temperature: $20^{\circ} \mathrm{C}$ ); this may explain why A. ovalisporum is detected in spring and autumn (Imai et al., 2009; Yamamoto, 2010).

In 2012, Aphanizomenon ovalisporum bloomed in June and October while Microcystis aeruginosa bloomed in August. However, in 2013, Aphanizomenon ovalisporum occurred for a short period in March and it was then replaced by chlorophyta species, then Microcystis aeruginosa was detected earlier in June. In comparison with year 2012, surface water temperature was higher in May 2013 and lower in June and July. This variation in water temperature and thermocline location with other parameters like nutrient availability, solar irradiation and discharge management may have prevented a steady growth phase Aphanizomenon ovalisporum in May and June 2013 and supported an earlier bloom of Microcystis aeruginosa.

Microcystis aeruginosa can outpace Aphanizomenon ovalisporum at high temperature due to its higher growth rate and competition for light. Although nitrogen limitation promotes Aphanizomenon ovalisporum, we think that it is a minor controlling factor in comparison to water temperature and the competitive eco-physiology of Microcystis aeruginosa in Karaoun Reservoir. Nitrogen limitation is not enough for Aphanizomenon ovalisporum to outgrow Microcystis aeruginosa that can also survive in low nitrogen availability conditions. Imai et al (2009) showed that Microcystis aeruginosa was able to grow in nitrogen-limited culture and its concentration was half the concentration reached after 12 days in culture without nutrient limitation. The availability of light has a major impact on the dynamics and structure of phytoplankton communities. Microcystis has a slightly lower critical light intensity than 
Aphanizomenon. Huisman et al. (1999) demonstrated that when they were placed in mixed culture to compete for light, Microcystis strains outpaced Aphanizomenon ones (Huisman et al., 1999). Laboratory experiments on the growth rate of Microcystis and Aphanizomenon strains of Lake Mendota (Wisconsin) showed that Microcystis had an apparent doubling time of 2 days in culture while Aphanizomenon needed 5.5 days (Konopka and Brock, 1978). Other laboratory experiments showed that Aphanizomenon ovalisporum has a maximum growth rate below 0.4 day $^{-1}$ (Hadas et al., 2002; Mehnert et al., 2010), lower than that of Microcystis aeruginosa that can reach 0.8 day $^{-1}$ (Chu et al., 2007; Zheng et al., 2008).

In Karaoun Reservoir, Aphanizomenon ovalisporum blooms occurred in spring and autumn at surface water temperature below $22{ }^{\circ} \mathrm{C}$, while a Microcystis aeruginosa blooms occurred in summer at $24-27{ }^{\circ} \mathrm{C}$. This succession can be explained by the fact that the growth of Microcystis sp. stops below $20{ }^{\circ} \mathrm{C}$ and is optimal at water temperatures ranging from 27.5 to $32{ }^{\circ} \mathrm{C}$ (Imai et al., 2009; Robarts and Zohary, 1987). In contrast, Aphanizomenon sp. has an optimal growth temperature ranging from 15 to $28^{\circ} \mathrm{C}$ (Robarts and Zohary, 1987) and is able to outgrow Microcystis sp. at lower temperatures (Miller et al., 2013). The competitive ecophysiology of Microcystis aeruginosa at high temperature could explain why Aphanizomenon ovalisporum blooms never occurred at water temperatures higher than $23{ }^{\circ} \mathrm{C}$ in Karaoun Reservoir.

Ceratium hirundinella was the only dinoflagellate detected in Karaoun Reservoir. It tended to develop in late summer 2013 during stratified conditions and had its biovolume peak in late autumn 2012 in a mixed water column after a decrease by $22 \mathrm{~m}$ in the water level. This does not agree with $C$. hirundinella populations in the close Lake Tiberias (Israel) that develop in winter and spring (Pollingher and Hickel, 1991). However, similarly to some Mediterranean reservoirs in Spain (Pérez-Martínez and Sánchez-Castillo, 2001), C. hirundinella dominated the phytoplankton assemblages in autumn and during both in stratified and mixed periods (Pérez-Martínez and Sánchez-Castillo, 2001). Matsumura-Tundisi et al. (2010) attributed Ceratium blooms in Billings Reservoir, Brazil, to the mixing and turbulence of the water column. In Karaoun Reservoir, C. hirundinella bloomed in November 2012 during mixing conditions after an increase in inflow volumes. An increase in nutrient concentrations due to inflows and mixing favoured by low water level could have removed Ceratium cysts from the sediment surface and promoted its growth as in Billings Reservoir.

Between June and July 2013, C. hirundinella in Karaoun Reservoir was more prevalent at 5$m$ depth rather than the surface due to the high irradiance that occured in these months. Whittington et al. (2000) revealed that Ceratium hirundinella in Chaffey Reservoir, a subtropical reservoir in northern New South Wales, Australia, formed subsurface accumulations at depths only when the light intensity was favourable for photosynthesis and cell growth (212-552 $\mu \mathrm{mol}$ photons $\mathrm{m}^{-2} \mathrm{~s}^{-1}$, equivalent to $\left.53-138 \mathrm{~W} \cdot \mathrm{m}^{-2}\right)$. At higher incident irradiance, $C$. hirundinella migrated downwards, avoiding high-light-induced.

The decrease in water level can indirectly affect the physical-chemical and biological characteristics of freshwater bodies, mainly through mixing enhancement (ValdespinoCastillo et al., 2014). Extreme decreases in reservoir water level can affect the thermal structure of the water column (Zohary and Ostrovsky, 2011). Our results show that in October 2012 (Figure 3), when the water level decreased by more than $15 \mathrm{~m}$ due to low inflow and continous withdrawal, thermal stratification was weakened and the water column was mixed. Naselli-Flores (2003) made a similar observation in Lake Arancio that has a maximum depth of $29 \mathrm{~m}$ where strong wind resulted in destratification after a $15 \mathrm{~m}$ decrease in water level 
(Naselli-Flores, 2003). The amount of energy required to mix the water column increases as the water level increases (Kling, 1988). The increase in maximum depth of Lake Elsinore from 5 to $10.5 \mathrm{~m}$ had a tremendous effect on the stability of its water column that increased as much as 4 times, from $18 \mathrm{~J} / \mathrm{m}^{2}$ to more than $60 \mathrm{~J} / \mathrm{m}^{2}$ (Lawson and Anderson, 2007).

Water level fluctuation affects nutrient profiles in reservoirs. External nutrient loading usually decrease with water level because of the decrease in inflows. However, the decrease in water level increases nutrient concentrations in the hypolimnion (Zohary and Ostrovsky, 2011) and can favour upward fluxes of sediment nutrients by internal waves (MacIntyre et al., 1999).

High water level and nutrient depletion at the epilimnion may have favoured the dominance of cyanobacteria on other phytoplankton groups in Karaoun Reservoir. During periods of high water level, thermal stratification is more stable and the hypolimnion is anoxic. Phosphorus is consumed by phytoplankton in the epilimnion and its concentration increases in the hypolimnion due to internal release from the sediments during anoxia (Nurnberg, 1984). This gives advantage to cyanobacteria that can overcome the epilimnetic phosphorus limitation during stratification due to their internal nutrient storage. They have a substantial storage capacity for phosphorus that allows them to increase their biomass by up to 32 folds (Chorus and Bartram, 1999). Even after depletion of this stock, cyanobacteria can migrate downwards to the metalimnion, where nutrient limitation is less severe (Camacho, 2006).

\section{Conclusion}

The information presented in this study increases the knowledge about phytoplankton dynamics in reservoirs with highly fluctuating water levels and in the Mediterranean region, and contribute to a safer water usage in Karaoun Reservoir. The phytoplankton community of Karaoun Reservoir has a seasonal pattern of spring chlorophyta and cyanobacteria blooms, summer-early autumn cyanobacterial blooms and late autumn dinoflagellate blooms. Variations in water temperature, stratification, irradiance and nutrient availability and water level result in different successions. Thermal stratification established in spring reduces the growth of diatoms that sink out of the euphotic zone. High nutrient availability during spring promotes green algae blooms at high water level and light intensity, stratified conditions and surface water temperatures lower than $22{ }^{\circ} \mathrm{C}$. The increase in surface water temperature (over $25^{\circ} \mathrm{C}$ ) and high irradiance conditions promote blooms of cyanobacterium Microcystis aeruginosa blooms in summer. Despite different growth conditions in other lakes and reservoirs, cyanobacterium Aphanizomenon ovalisporum dominated at surface temperatures lower than $23{ }^{\circ} \mathrm{C}$ in weakly stratified conditions in early autumn and dinoflagellate Ceratium hirundinella dominated in mixed conditions, at low light intensity in late autumn at $19{ }^{\circ} \mathrm{C}$. These different growth conditions might be a result of the high water fluctuation of the reservoir.

Reservoir managers in Karaoun Reservoir can take advantage of this repetitive succession pattern and reduce the nutrient influx from the upstream watershed to the reservoir to avoid the long steady state of these blooms.

\section{Acknowledgments}

This work was funded by Ecole des Ponts ParisTech, as well as by the Lebanese National Council for Scientific Research - Lebanese Atomic Energy Commission, the French Ministry 
for Higher Education and Research and the French Ministry for Foreign Affairs through the CEDRE program (project 10 EF 38/L9).

\section{References}

Arif, S., 2013. Cost of Water Resources Degradation (CAWRD) of the Litani Basin. National consultation workshop on the cost of the environmental degradation and remediation of the Litani River Basin (Lebanon), December 12, 2013, Beirut, Lebanon.

Atoui, A., Hafez, H., Slim, K., 2013. Occurrence of toxic cyanobacterial blooms for the first time in Lake Karaoun, Lebanon. Water and Environment Journal 27, 42-49.

Camacho, A., 2006. On the occurrence and ecological features of deep chlorophyll maxima (DCM) in Spanish stratified lakes. Limnetica 25, 453-478.

Chorus, I., Bartram, J., 1999. Toxic Cyanobacteria in Water: A guide to their public health consequences, monitoring and management. E \& FN Spon, published on behalf of the World Health Organization, New York.

Chu, Z.S., Jin, X.C., Iwami, N., Inamori, Y.H., 2007. The effect of temperature on growth characteristics and competitions of Microcystis aeruginosa and Oscillatoria mougeotii in a shallow, eutrophic lake simulator system. Hydrobiologia 581, 217-223.

Domis, L.N.D.S., Elser, J.J., Gsell, A.S., Huszar, V.L.M., Ibelings, B.W., Jeppesen, E., Kosten, S., Mooij, W.M., Roland, F., Sommer, U., Van Donk, E., Winder, M., Lurling, M., 2013. Plankton dynamics under different climatic conditions in space and time. Freshwater Biology 58, 463-482.

ELARD (Earth Link and Advanced Resources Development), 2011. Business plan for combating pollution of the Qaraoun Lake, UNDP ed., Beirut, Lebanon.

Fadel, A., Lemaire, B.J., Atoui, A., Vinçon-Leite, B., Amacha, N., Slim, K., Tassin, B., 2014a. First assessment of the ecological status of Karaoun Reservoir, Lebanon. Lakes \& Reservoirs: Research \& Management 19, 142-157.

Fadel, A., Atoui, A., Lemaire, B., Vinçon-Leite, B., Slim, K., 2014b. Dynamics of the toxin cylindrospermopsin and the cyanobacterium Chrysosporum (Aphanizomenon) ovalisporum in a Mediterranean eutrophic reservoir Toxins 6, 3041-3057.

Hadas, O., Pinkas, R., Malinsky-Rushansky, N., Shalev-Alon, G., Delphine, E., Berner, T., Sukenik, A., Kaplan, A., 2002. Physiological variables determined under laboratory conditions may explain the bloom of Aphanizomenon ovalisporum in Lake Kinneret. European Journal of Phycology 37, 259-267.

Huisman, J., Jonker, R.R., Zonneveld, C., Weissing, F.J., 1999. Competition for light between phytoplankton species: experimental tests of mechanistic theory. Ecology 80, 211-222.

Huisman, J., Sharples, J., Stroom, J.M., Visser, P.M., Kardinaal, W.E.A., Verspagen, J.M.H., Sommeijer, B., 2004. Changes in turbulent mixing shift competition for light between phytoplankton species. Ecology 85, 2960-2970.

Imai, H., Chang, K.H., Nakano, S., 2009. Growth responses of harmful algal species Microcystis (cyanophyceae) under various environmental conditions. In: Obayashi Y, Isobe T, Subramanian A, Suzuki S, Tanabe S (eds) Interdisciplinary Studies on Environmental Chemistry-Environmental Research in Asia, pp 269-275.

Kling, G.W., 1988. Comparative transparency, depth of mixing, and stability of stratification in lakes of Cameroon, West Africa. Limnology and Oceanography 33, 27-40.

Komárek, J., Anagnostidis, K., 1999. Cyanoprokaryota 1 Teil: Chroococcales. Ettl, H., Gärtner, G., Heynig, G.H. \& Mollenhauer, D. (eds), Süßwasserflora von Mitteleuropa Band 19/1, Spektrum Akademischer Verlag. 
Komárek, J., Anagnostidis, K., 2005. Cyanoprokaryota 2 Teil: Oscillatoriales. Büdel, B., Gärtner, G., Krienitz, L. \& Schagerl, M (eds), Süßwasserflora von Mitteleuropa Band 19/2, Spektrum Akademischer Verlag (Elsevier).

Konopka, A., Brock, T.D., 1978. Effect of Temperature on Blue-Green Algae (Cyanobacteria) in Lake Mendota. Appl. Environ. Microbiol. 36, 572-576.

Korfali, S., Jurdi, M., 2010. Speciation of metals in bed sediments and water of Qaraaoun Reservoir, Lebanon. Environmental Monitoring and Assessment 178, 563-579.

Lance, E., Brient, L., Carpentier, A., Acou, A., Marion, L., Bormans, M., Gérard, C., 2010. Impact of toxic cyanobacteria on gastropods and microcystin accumulation in a eutrophic lake (Grand-Lieu, France) with special reference to Physa (= Physella) acuta. Science of The Total Environment 408, $3560-3568$.

Lawson, R., Anderson, M.A., 2007. Stratification and mixing in Lake Elsinore, California: An assessment of axial flow pumps for improving water quality in a shallow eutrophic lake. Water Research 41, 4457-4467.

Li, F., Zhang, H., Zhu, Y., Xiao, Y., Chen, L., 2013. Effect of flow velocity on phytoplankton biomass and composition in a freshwater lake, Science of The Total Environment 447, 64-71.

Lorenzen, C.J., 1967. Determination of chlorophyll and phaeo-pigments: spectrophotometric equations. Limnology and Oceanography 12, 343-346.

Lynne M.W., 2004. Practical Guide to Identifying Freshwater Crustacean Zooplankton, Laurentian University Press, Ontario, Canada, 60 p.

MacIntyre, S., Flynn, K.M., Jellison, R., Romero, J.R., 1999. Boundary mixing and nutrient fluxes in Mono Lake, California. Limnology and Oceanography 44, 512-529.Matsumura-Tundisi, T., Tundisi, J., Luzia, A., Degani, R., 2010. Occurrence of Ceratium furcoides (Levander) Langhans 1925 bloom at the Billings Reservoir, Sao Paulo State, Brazil. Brazilian Journal of Biology 70, 825-829.

Mehnert, G., Leunert, F., Cirés, S., Jöhnk, K.D., Rücker, J., Nixdorf, B., Wiedner, C., 2010. Competitiveness of invasive and native cyanobacteria from temperate freshwaters under various light and temperature conditions. Journal of Plankton Research 32, 1009-1021.

Miller, T., Beversdorf, L., Chaston, S., McMahon, K., 2013. Spatiotemporal molecular analysis of cyanobacteria blooms reveals Microcystis-Aphanizomenon interactions. PLoS ONE 8, e74933. doi:74910.71371/journal.pone.0074933.

Naselli-Flores, L., 2003. Man-made lakes in Mediterranean semi-arid climate: the strange case of Dr Deep Lake and Mr Shallow Lake. Hydrobiologia 506-509, 13-21.

Naselli-Flores, L., Barone, R., 1997. Importance of water-level fluctuation on population dynamics of cladocerans in a hypertrophic reservoir (Lake Arancio, south-west Sicily, Italy). Hydrobiologia 360, 223-232.

Niehaus, T.D., Kinison, S., Okada, S., Yeo, Y.-s., Bell, S.A., Cui, P., Devarenne, T.P., Chappell, J., 2011. Functional Identification of Triterpene Methyltransferases from Botryococcus braunii Race B. Journal of Biological Chemistry 287, 8163-8173.

Nurnberg, G.K., 1984. The prediction of internal phosphorus load in lakes with anoxic hypolimnia. Limnology and Oceanography 29, 111-124.

Pérez-Martínez, C., Sánchez-Castillo, P., 2001. Temporal occurrence of Ceratium hirundinella in Spanish reservoirs. Hydrobiologia 452, 101-107.

Pollingher, U., Hickel, B., 1991. Dinoflagellate associations in a subtropical lake (Lake Kinneret, Israel). Arch. Hydrobiol. 120, 267-285.

Reynolds, C.S., 2006a. Nutrient uptake and assimilation in phytoplankton, The Ecology of Phytoplankton. Cambridge University Press, United States of America, pp. 145-175. 
Reynolds, C.S., 2006b. The Ecology of Phytoplankton. Cambridge University Press, United States of America.

Robarts, R.D., Zohary, T., 1987. Temperature effects on photosynthetic capacity, respiration, and growth rates of bloom-forming cyanobacteria. New Zealand Journal of Marine and Freshwater Research 21, 391 - 399.

Romo, S., Soria, J., Fernandez, F., Ouahid, Y., Baron-Sola, A., 2013. Water residence time and the dynamics of toxic cyanobacteria. Freshwater Biology 58, 513-522.

Segura, A.M., Kruk, C., Calliari, D., Fort, H., 2013. Use of a morphology-based functional approach to model phytoplankton community succession in a shallow subtropical lake. Freshwater Biology 58, 504-512.

Sherman, B.S., Webster, I.T., Jones, G.J., Oliver, R.L., 1998. Transitions between Aulacoseira and Anabaena dominance in a turbid river weir pool. Limnology and oceanography 43, 1902-I1915.

Slim, K., Fadel, A., Atoui, A., Lemaire, B.J., Vinçon-Leite, B., Tassin, B., 2014. Global warming as a driving factor for cyanobacterial blooms in Lake Karaoun, Lebanon. Desalination and Water Treatment 52, 2094-2101.

Smith K., Fernando C.H., 1978. A guide to the freshwater calanoid and cyclopoid copepod Crustacea of Ontario. University of Waterloo, Canada, $74 \mathrm{p}$.

Smith, V., 2003. Eutrophication of freshwater and coastal marine ecosystems a global problem. Environmental Science and Pollution Research 10, 126-139.

Sommer, U., Gliwicz, Z.M., 1986. Long-range vertical migration of Volvox in tropical lake, Cabora Bassa (Mozambique). Limnology and Oceanography 31, 650-653.

Stemberger, R.S. 1979. A guide to rotifers of the Laurentian Great Lakes. U.S. Environmental Protection Agency, Rept. No. EPA 600/4-79-021.

Sun, J., Liu, D., 2003. Geometric models for calculating cell biovolume and surface area for phytoplankton. Journal of Plankton Research 25, 1331-1346.

USAID (United States Agency for International Development), 2012a. Litani River Basin Management Support Program. Litani River constructed treatment wetland design report.

USAID (United States Agency for International Development), 2012b. Litani River Basin Management Support Program. Feasibility study for constructed wetlands in the Litani River Basin.

Valdespino-Castillo, P., Merino-Ibarra, M., Jiménez-Contreras, J., Castillo-Sandoval, F., RamirezZierold, J.A., 2014. Community metabolism in a deep (stratified) tropical reservoir during a period of high water-level fluctuations. Environmental Monitoring and Assessment 186, 6505-6520.

Weiss, T.L., Roth, R., Goodson, C., Vitha, S., Black, I., Azadi, P., Rusch, J., Holzenburg, A., Devarenne, T.P., Goodenough, U., 2012. Colony organization in the green alga Botryococcus braunii (Race B) is specified by a complex extracellular matrix. Eukaryotic Cell 11, 1424-1440.

Whittington, J., Sherman, B., Green, D., Oliver, R.L., 2000. Growth of Ceratium hirundinella in a subtropical Australian reservoir: the role of vertical migration. Journal of Plankton Research 22, 10251045.

Yamamoto, Y., 2010. Contribution of bioturbation by the red swamp crayfish Procambarus clarkii to the recruitment of bloom-forming cyanobacteria from sediment. Journal of Limnology 69, 102-111.

Zheng, Z.M., Bai, P.F., LU, K.H., Jin, C.H., Zhang, L., 2008. Growth characteristics and competitive parameters of Microcystis aeruginosa and Scendesmus quadricauda at different temperatures. Acta Hydrobiologica Sinica, 720-727.

Zohary, T., Ostrovsky, I., 2011. Ecological impacts of excessive water level fluctuations in stratified freshwater lakes. Inland Waters 1, 47-59. 